Journal of Bangladesh Academy of Sciences, Vol. 37, No. 2, 211-217, 2013

\title{
PHYLLOPLANE MYCOFLORA OF GERBERA SPP. AND THEIR PATHOGENIC POTENTIALITY
}

\author{
FATEMA YEASMIN ${ }^{1}$ AND SHAMIM SHAMSI* \\ Department of Botany, University of Dhaka. Dhaka-1000, Bangladesh
}

\begin{abstract}
Two types of symptoms, blight and anthracnose, were recorded on two species of Gerbera viz. Gerbera aurantiaca L. and Gerbera viridifolia $\mathrm{L}$. The most common fungal species isolated from Gerbera spp. were Alternaria citrii, A. tennuisssima, Aspergillus flavus, A. fumigatus, A. niger, A. terreus, Bipolaris hawaiiensis, Chaetomella raphigera, Cladosporium cladosporoides, Colletotrichum capsici, C. coffeanum, C. dematium, C. gleosporioides, C. lindemuthianum, C. musae, C. orbiculare, Colletorichum $\mathrm{sp}_{\cdot 1}$, Colletotrichum $\mathrm{sp}_{.2}$, Colletotrichum $\mathrm{sp}_{\cdot 3}$, Colletotrichum $\mathrm{sp}_{4}$, Curvularia clavata, C. lunata, Fusarium nivale, F. semitectum, Phomopsis sp., Penicillium sp., Pestalotia sp., Rhizopus stolonifer, Trichoderma viride, one cleistothecial ascomycetes and one sterile fungus. The frequency percentage of association of Colletotrichum spp. with Gerbera spp. was higher than any other fungi. Bipolaris hawaiiensis is a new record for Bangladesh. Among the isolated fungi Alternaria citrii, A. tennuissima, Colletotrichum capcisi, C. dematium, C. coffeanum and Curvularia clavata were found to be pathogenic to Gerbera plant.
\end{abstract}

Key words: Phylloplane, Mycoflora, Gerbera spp., Pathogenic, Potentiality

\section{INTRODUCTION}

Gerbera is a genus of the family of Sunflowers, Daisies and Asters-Asteraceae. It was named in honour of the German botanist and naturalist Traugott Gerber (1743). It has approximately 30 species in the wild. The first scientific description of a Gerbera was made by J.D. Hooker in Curtis's Botanical Magazine in 1889 when he described Gerbera jamesonii, a South African species. Gerbera is also commonly known as the African Daisy. Gerbera is very popular and widely used as a decorative garden plant or as cut flowers. The domesticated cultivars are mostly a result of a cross between Gerbera jamesonii and another South African species Gerbera viridifolia. Thousands of cultivars exist. They vary greatly in shape and size. Colours include white, yellow, orange, red, and pink. Gerbera is also important commercially. It is the fifth most used cut flower in the world (after rose, carnation, chrysanthemum, and tulip). Daisies are often used in floral arrangements. The meanings of Gerbera flowers include innocence and purity. The long-lasting daisy's simple structure and cheerful look make it easy to combine with other desirable flowers in arrangements.

* Corresponding author: <Prof.shamsi@gmail.com>.

${ }^{1}$ A part of M.S. Thesis of first author. 
In Bangladesh Gerbera was first introduced in Godhkhali of Zhikorgasa, It is commercially grown in Rajshahi and Jessore. Now the plants are cultivated throughout the country as garden plant. The plants are attacked by insects, pests and fungi. The fungal diseases are usually leaf spot, leaf blight. Botrytis blight, powdery mildew, Fusarium stem rot, Rhizoctonia crown rot, Sclerotium rot, Thielaviopsis root rot white rot and rust. Research about its fungal diseases is inadequate. Present study was undertaken to find the fungi associated with different varieties of Gerbera. The objectives include: (1) Isolation, characterization and identification of fungi associated with two varieties of Gerbera and (2) to study the pathogenic potentiality of the isolated fungi.

\section{MATERIALS AND METHODS}

The present study is based on healthy and affected leaves of Gerbera spp. Plant materials were collected from Dhanmondi, Gulshan, Farmgate, Mirpur, Mohakhali and Dhaka University Campus, during September 2011 to November 2012. Two types of symptoms, blight and anthracnose, were recorded on two species of Gerbera viz. Gerbera aurantiaca (red flower), Gerbera aurantiaca (orange flower) and Gerbera viridifolia (pink flower) (Fig. 1. A-I).

The fungi were isolated from the samples following the "Tissue Planting method". The specimens were cut into small pieces $(2 \mathrm{~mm} \times 2 \mathrm{~mm})$ and surface sterilized by dipping in $10 \%$ chlorox for 3-5 minutes followed by rinsing in sterilized water. Surface sterilized plant pieces were placed on PDA medium (Tuite 1969). From each sample 30 inocula consisted of leaf pieces were taken and placed on solidified PDA in Petri dishes at 3 pieces per plate. The plates were incubated for 5-7 days at $25 \pm 1{ }^{\circ} \mathrm{C}$. Fungi grew from the inocula were transferred to separate PDA plates and PDA slants for further studies and preservation. The isolated fungi were identified based on morphological characteristics observed under a compound microscope following standard keys (Barnett and Hunter 2000, Booth 1971, Ellis 1971, 1976, Ellis and Ellis 1997, Sutton 1980). Prevalence (\%) of fungi in different specimens was also recorded.

Pathogenicity of the isolated fungi was tested following modified 'detached leaf technique' (Azad and Shamsi 2011). Healthy and mature leaves of Gerbera spp. were collected. Leaves were washed with distilled water, surface sterilized with $10 \%$ Clorox for five minutes and rinsed in sterilized water. Leaves were cut into $25^{2} \mathrm{~mm}$ in size

from the centre. Ventral and dorsal sides of the leaf pieces with and without pricking were inoculated with spores of the isolated fungi. Another set of leaves with and without pricking and without inoculation were maintained, which served as controls. The inoculated leaf pieces were placed in Petri dishes containing water soaked cotton bar to maintain sufficient humidity to initiate infection. The plates were incubated at $25-28^{\circ} \mathrm{C}$. After 3 days of inoculation, examination of leaves under pathogenicity test was started and continued for 7-10 days for disease development. 

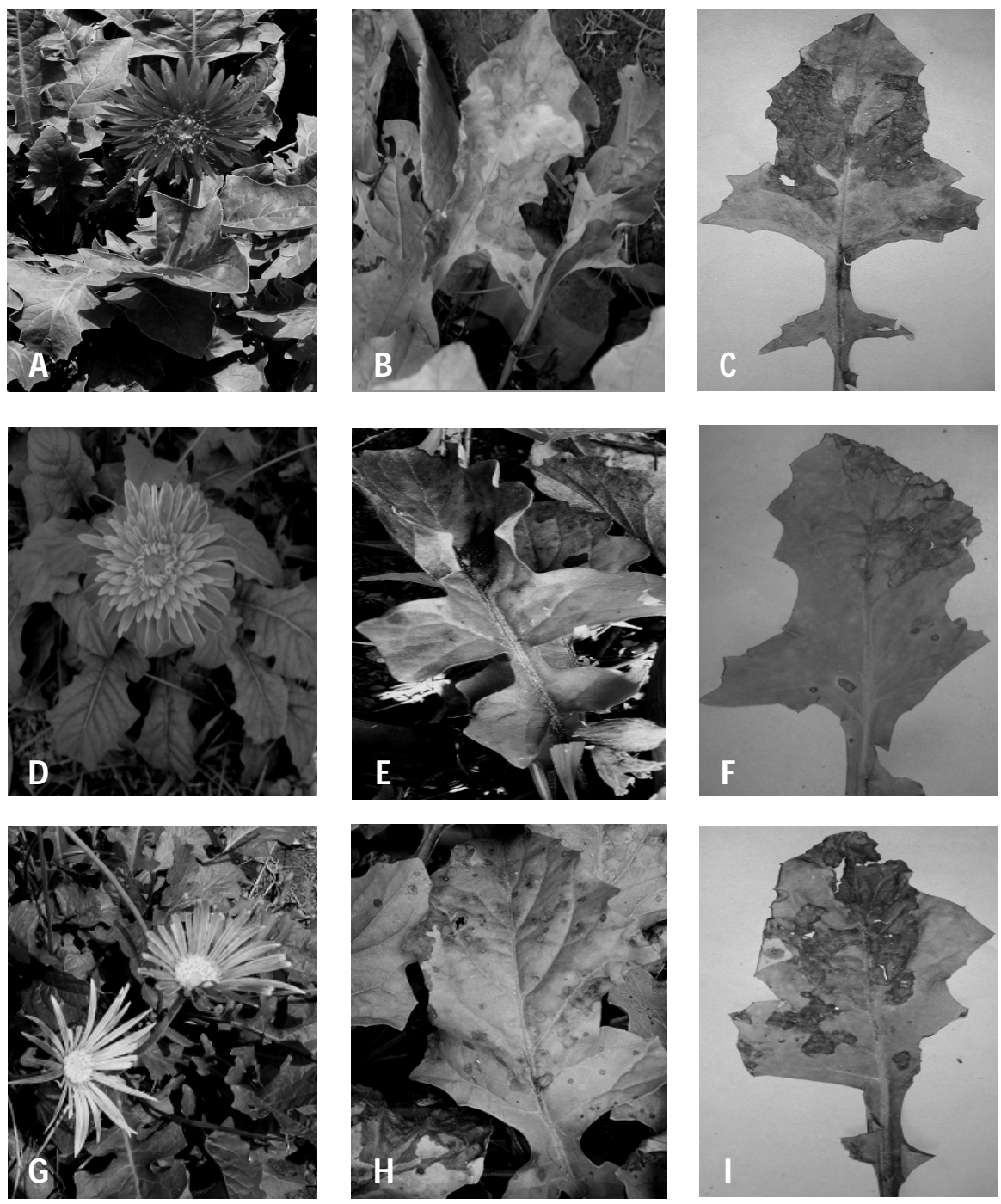

Fig. 1. Gerbera aurantiaca: A. Healthy plants. B-C. Plants and leaf with blight symptom. Gerbera aurantiaca: Healthy plants. E-F. Plants and leaf with anthracnose symptom. gerbera viridifolia: G. Healthy plants, H-I. Plants and leaf with anthracnose symptom.

\section{RESULTS AND DISCUSSION}

Altogether 16 species of fungi were isolated from the healthy leaves of Gerbera aurantiaca (red flower). In order of their prevalence they were Aspergillus niger, Alternaria citri, Pestalotia sp., Curvularia clavata, Penicillium sp., Aspergillus terreus, Cladosporium cladosporioides, Colletotrichum orbiculare, Aspergillua fumigatus, Bipolaris hawaiiensis, Colletotrichum dematium, Alternaria tennuissima, sterile fungus, 
Rhizopus stolonifer, Trichoderma viride and Aspergillus flavus,. Their prevalence was $13.05,12.86,9.27,8.06,7.13,6.48,4.10,3.13,2.86,2.59,2.27,1.56,1.52$ and $1.18 \%$, respectively.

Leaves of Gerbera aurantiaca (red flower) infected with blight yielded 11 species of fungi. Prevalence of Alternaria citri was the highest followed by Alternaria tennuissima, Penicillium sp., Aspergillus niger, Curvularia clavata, Aspergillus flavaus, Colletotrichum lindemuthianum, Colletotrichum orbiculare, Aspergillus terreus and Colletotrichum gloeosporioides. The prevalence of the fungi was 27.34, 23.21, 9.91, $9.35,8.21,6.46,3.33,2.59$, and $1.72 \%$, respectively (Table 1 ).

Table 1. Prevalence of different fungi associated with healthy and blight infected leaves of Gerbera aurantiaca (red flower).

\begin{tabular}{lcc}
\hline & Healthy leaves & Leaves with bight \\
\cline { 2 - 3 } & Gerbera aurantiaca (red flower) & Gerbera aurantiaca (red flower) \\
\hline Alternaria citri & 12.86 & 27.34 \\
Alternaria tennuissima & 2.27 & 23.21 \\
Aspergillus flavus & 1.18 & 6.46 \\
Aspergillus fumigatus & 2.86 & \\
Aspergillus niger & 13.05 & 9.35 \\
Aspergillus terreus & 6.48 & 3.33 \\
Bipolaris hawaiiensis & 2.59 & - \\
Cladosporium cladosporioides & 4.10 & - \\
Colletotrichum dematium & 2.59 & - \\
Colletotrichum gloeosporioides & - & 1.72 \\
Colletotrichum lindemuthianum & - & 6.46 \\
Colletotrichum orbiculare & 3.13 & 6.46 \\
Curvularia clavata & 8.06 & 8.21 \\
Penicillium sp. & 7.13 & 9.91 \\
Pestalotia sp. & 9.27 & - \\
Rhizopus stolonifer & 1.52 & - \\
Trichoderma viride & 1.52 & - \\
Sterile fungus & 1.56 & 2.59 \\
\hline “" & &
\end{tabular}

"-" not isolated.

Altogether 15 species of fungi were isolated from the healthy leaves of Gerbera aurantiaca (orange flower). In order of their prevalence those were Colletotrichum dematium, Colletotrichum coffeanum, Aspergillus niger, Colletotrichum gloeosporioides, Colletotrichum orbiculare, Pestalotis sp., Colletotrichum musae, Aspergillus flavus, Colletotrichum sp.2, Colletotrichum sp.3, Penicillium sp., Chaetomella raphigera, Phomopsis sp., Fusarium nivale and a sterile fungus. Their prevalence was 18.99, 12.82, $8.77,7.29,6.90,6.80,6.34,6.06,5.43,3.13 .3 .03,2.02 \%$, respectively. Leaves of $G$. 
aurantiaca (orange flower) infected with anthracnose symptoms yielded 13 species of fungi. Prevalence of Colletotrichum gloeosporioides was highest $13.90 \%$ was followed by $C$. dematium $(12.04 \%)$ and C. musae (11.94\%). The lowest prevalence was found in Aspergillus flavus (3.42\%), Curvularia lunata (3.42\%), Penicillium sp. (3.42\%), Colletotrichum sp.2 (3.42\%), Curvularia clavata (3.92\%), Colletotrichum $\mathrm{sp}_{.1}(4.04 \%)$, Colletotrichum sp.4 (5.13\%), Colletotrichum capsici (5.88\%), Colletotrichum orbiculare (6.84\%) and Aspergillus niger (7.96\%), (Table 2).

Table 2. Prevalence of different fungi associated with healthy and anthracnose infected leaves of Gerbera aurantiaca (orange flower) and Gerbera viridifolia.

\begin{tabular}{|c|c|c|c|c|}
\hline Name of isolates & $\begin{array}{l}\text { Healthy leaves } \\
\text { Gerbera aurantiaca } \\
\text { (orange flower) }\end{array}$ & $\begin{array}{c}\text { Gerbera } \\
\text { viridifolia }\end{array}$ & $\begin{array}{c}\text { Leaves with anthracnose } \\
\text { Gerbera aurantiaca } \\
\text { (orange flower) }\end{array}$ & $\begin{array}{c}\text { Gerbera } \\
\text { viridifolia }\end{array}$ \\
\hline Aspergillus flavus & 6.34 & - & 3.42 & 4.17 \\
\hline Aspergillus fumigatus & - & - & - & 9.57 \\
\hline Aspergillus niger & 8.77 & 8.25 & 7.96 & 4.17 \\
\hline Chaetomella raphigera & 3.13 & - & - & - \\
\hline Colletotrichum capsici & - & - & 5.88 & - \\
\hline Colletotrichum coffeanum & 12.82 & 10.75 & - & 19.14 \\
\hline Colletotrichum dematium & 18.99 & 16.22 & 12.04 & - \\
\hline Colletotrichum gloeosporioides & 7.29 & 15.56 & 13.90 & - \\
\hline Colletotrichum lindemuthianum & - & - & - & 20.91 \\
\hline Colletotrichum musae & 6.80 & 8.89 & 11.94 & 8.34 \\
\hline Colletotrichum orbiculare & 7.29 & 6.67 & 6.84 & 8.34 \\
\hline Colletotrichum sp.1 & - & - & 4.04 & - \\
\hline Colletotrichum $\mathrm{sp}_{\cdot 2}$ & 6.06 & - & 3.42 & - \\
\hline Colletotrichum $\mathrm{sp} .3$ & 3.03 & 6.45 & - & - \\
\hline Colletotrichum sp.4 & - & - & 5.13 & - \\
\hline Curvularia clavata & - & - & 3.92 & - \\
\hline Curvularia lunata & - & - & 3.42 & 4.44 \\
\hline Fusarium nivale & 2.02 & - & - & - \\
\hline Fusarium semitectum & - & 1.33 & - & 9.57 \\
\hline Penicillium sp. & 5.43 & 10.05 & 3.42 & - \\
\hline Pestalotia sp. & 6.90 & - & - & - \\
\hline Phomopsis sp. & 3.03 & - & - & - \\
\hline Sterile fungus & 2.02 & 6.08 & - & 4.17 \\
\hline
\end{tabular}

"_" not isolated.

Ten species of fungi, namely Colletotrichum dematium, Colletotrichum gloeosporioides, C. coffeanum, Penicillium sp., C. musae, Aspergillus niger, $C$. orbiculare, Colletotrichum sp..3, Sterile fungus and Fusarium semitectum were isolated from the healthy leaves of Gerbera viridifolia. The prevalence of these fungi were 16.22, 
$15.56,10.75,10.05,8.89,8.25,6.67,6.45,6.08$, and $1.33 \%$, respectively. Ten species of fungi were associated with anthracnose infected leaves of Gerbera viridifolia. The prevalence ranged from 4.17-20.91\%. Among the fungi Aspergillus flavus, A. fumigatus, A. niger, Colletotrichum coffeanum, Colletotrichum lindemuthianum, C. musae, C. orbiculare, Curvularia lunata, Fusarium semitectum and a sterile fungus were isolated from the infected leaves of G. viridifolia. Prevalence of Colletotrichum lindemuthianum was the highest (20.91\%) and C. Curvularia lunata was the lowest (4.44\%) (Table 2).

Among the isolated fungi Alternaria citrii, A. tennuissima, Colletotrichum capcisi, C. dematium, C. coffeanum and Curvularia clavata were found to be pathogenic to Gerbera plant (Fig. 2 A-L).
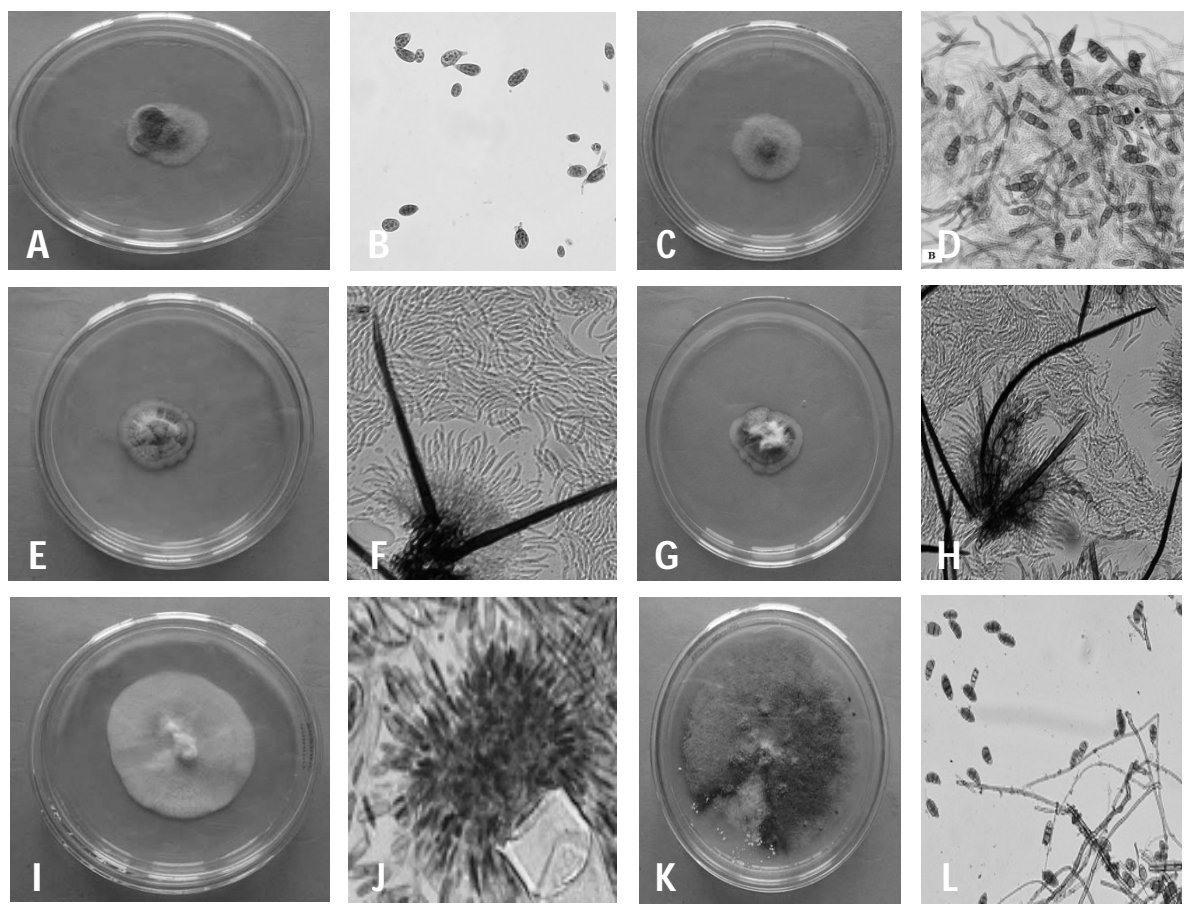

Fig. 2. A-B. Colony and conidia of Alternaria citrii, C-D. Colony, conidiophores and conidia of A. tennuissima, E-F. Colony and acervulus of Colletotrichum capcisi, G-H. Colony and acervulus of $C$. dematium, I-J. Colony and acervulus of $C$. coffeanum and K-L. Colony, conidiophore and conidia of Curvularia clavata $($ Bar $=50 \mu \mathrm{m})$.

From Bangladesh this is the first report of blight and anthracnose diseases of Gerbera spp. At the same time this is the first report of association of fungi with the symptom and symptom-less leaves of the plant and their pathogenic potentiality. Probably this is also first report on Anthracnose symptom of Gerbera spp. and its causal organism Colletotrichum spp. 


\section{REFERENCES}

Azad, R. and S. Shamsi. 2011. Identification and pathogenic potentiality of fungi associated with Huttuyania cordata Thunb. Dhaka Univ. J. Biol. Sci. 20(2):131-138.

Barnett, H. L. and B. Hunter. 2000. Illustrated Genera of Imperfect Fungi. (4th edn.), Burgessbub. Co. Minneapolis. pp. 218.

Booth, C. 1971. The Genus Fusarium. The Commonwealth Mycological Institute. England. pp. 273.

Ellis, M. B. 1971. Dematiaceous Hyphomycetes. The Commonwealth Mycological Institute, England, pp. 608.

Ellis, M. B. 1976. More Dematiaceous Hyphomycetes. The Commonwealth Mycological Institute, England, pp. 507.

Ellis, M. B. and J. P. Ellis. 1997. Micro fungi on Landplants. An Identification Handbook. pp. 868.

Sutton, B. C. 1980. The Coelomycetes, Fungi Imperfecti with pycnidia Acervuli and stroma. Commonwealth Mycological Institute. England. pp. 525-537.

Tuite, J. 1969. Plant Pathological methods. Fungi and Bacteria. Burgess Publishing Company. Minneapolis, Minnesota. USA. pp. 239.

(Received revised manuscript on 8 September, 2013) 